\title{
THE NEW NORMAL IN EDUCATION: A CHALLENGE TO THE PRIVATE BASIC EDUCATION INSTITUTIONS IN THE PHILIPPINES?
}

\author{
*Ruel F. Ancheta, Ed.D. \\ Gulf College, Sultanate of Oman \\ ruel@gulfcollege.edu.om \\ Helen B. Ancheta, MAEd \\ St. Vincent Blessed School of Manila, Philippines \\ helenbancheta@yahoo.com
}

*corresponding author

\begin{abstract}
This article aims to examine and discuss the challenges faced by the private basic education institutions in the Philippines as an effect of the Covid-19 pandemic. This pandemic has brought a dilemma to educational institutions especially when the government announced and ordered not to open face to face classes for Academic Year 2020 - 2021 until the Covid19 vaccine. In response to this order, the Department of Education (DepEd) released department order nos. 007, 12, 13, and 14 series of 2020 instructing all basic education institutions to come up with their learning continuity plan (LCP) and health and safety protocols in the new normal in education during the pandemic. The bigger challenge is now passed on to the private basic education schools. Literature cited herein develop a framework as to the necessary measures every private basic education institutions must do in the reopening of the schools. As there are limited studies written on the same nature, the author suggests a thorough study on the various facets of the online learning involving the children of the private basic education institutions.
\end{abstract}

Keywords: challenges, private education institutions, learning continuity plan, new normal 


\section{Introduction}

The operation of the private basic education institutions in the country and around the world was severely affected by the COVID-19 pandemic which began in December 2019. It became a worldwide health crisis where everyone were literally affected regardless of age, gender and social status. The world stopped and economy collapsed as all businesses shutdown operations. For instance, most countries closed the schools, colleges and universities to contain the spread of the virus. The crisis became a dilemma not only to the health sectors but also to the education sectors. When the Philippine government ordered closures of all educational institutions, the disruptions were sudden since classes were still running. At the height of the pandemic, educational institutions came out with remote learning as an alternative solution. The immediate action and strategy aims to mitigate the closure while continuously delivering quality education.

The sudden shift to online learning created a hot debate in the Philippines citing the poor living conditions of the learners. Magsambol (2020) cites an obvious gap between those who can and cannot afford the resources to avail the new education platform. The general condition of children in the public school system sends a message of inequality with the DepEd's mantra 'no child left behind.' However, learning cannot be cancelled as much as to drive the economy. This led to a tighter measures for education institutions in sustaining its operations despite the impending risk.

One of the basic problems seen by Kasrekar (2020) is the conduct of classes despite of the closure order. As the face to face classes pose higher risk of spread, the most viable solution is through online teaching and learning. This platform challenges both the teachers and the students as it occurs something new to them. This calls for an 'adopt quickly' response to the new normal in teaching and learning amidst the pandemic (TanhuecoTumapon, 2020). The shift to online learning was too sudden at a very short notice but academic institutions have to strategize and accelerate new forms of teaching pedagogy. The question of how ready the schools are in terms of technical infrastructure is still left unanswered. Reopening of the schools at this stage is really expensive (Felter \& Maizland, 2020). 
INTERNATIONAL JOURNAL OF EDUCATIONAL MANAGEMENT AND

DEVELOPMENT STUDIES

Volume 1, Issue 1 · September 2020 • ISSN 2719-0633 (PRINT) 2719-0641 (ONLINE)

The current educational situation in the Philippines seem depressing. From the latest data release by the Department of Education as of July 2020, the initial enrollment is just a little over half of the 2019's 27.7 million students. The decline in the number of enrollees is mainly attributed to financial factors and access to internet. While the public school system struggles for the resources in the remote learning, the private educational institutions face bigger threats of closure. In the DepEd data, only 866,935 registered in the private schools, a decline from 4 million in 2019. There are over 200,000 students who transferred from private to public schools due to economic downturn. Magsambol (2020) cites that the Coordinating Council of Private Educational Associations posed threat of closure of over 400 private schools due to lack of enrollees.

Private basic education institutions in the Philippines are not funded by the government. They operate in accordance with the laws and regulations set by DepEd and follow the same curriculum as the public schools. The public school is basically free, but parents with financial capacity opt to send their children to private schools due to smaller class size and better facilities and resources. The role of the private basic education institutions in the Philippines play a vital role in educating the minds of young Filipinos in terms of quality services (Acidre, 2019). The House Bill 4813 created the Bureau of Private Schools (BPS) that regulates the conduct of educational programs of all private basic education institutions in accordance with the DepEd standards. The bureau undertakes studies and prepares prototype curricular designs and guidelines to improve the curricular offerings of the private schools. All the programs and activities of the private education institutions are still under the supervision of DepEd (Carcamo 2014).

This article examines the challenges faced by the private basic education institutions in the Philippines brought by the effect of the Covid-19 pandemic. It particularly assesses the different factors considered prior to the reopening and how it changes the operations of the private schools. It presents the requirements set by the government and the challenges faced by the schools in compliance to the orders.

\section{Methodology}

This study is a literature review. Literature-based methodology is an effective tool to provide description, summary and critical evaluation of the existing literatures as the sources 
INTERNATIONAL JOURNAL OF EDUCATIONAL MANAGEMENT AND

DEVELOPMENT STUDIES

Volume 1, Issue 1 · September 2020 • ISSN 2719-0633 (PRINT) 2719-0641 (ONLINE)

of information. It can also broadly described as a systematic way of collecting and synthesizing previous research (Snyder, 2019).

The sources of information were the various DepEd orders which include DepEd Order Nos. 007, 013, and 014 s. 2020. In addition, the DOH AO No. 0015 s. 2020 was used. The author reviewed the contents of the DepEd Orders and DOH administrative orders to develop a framework of preparations checklist for the opening of classes in the new normal for School Year 2020-2021. After identifying all the requirements, details were presented and discussed. The author based the arguments from the current situations as well as cited literature and studies. Due to the limited studies in the Philippines, the actual experience of the authors in running their own private school were considered for the analysis and discussion.

\section{Results and Discussion}

Most countries all over the world are focused on how to start the new school year within the 'new normal' of teaching and learning without depriving the students of their right to quality education. The public and private academic institutions in the Philippines are instructed by DepEd to come up with a learning continuity plan (LCP) for school year 2020 2021. LCP is a package of education intervention in response to the challenges in basic education brought by Covid-19 pandemic. This strategic plan is designed to carry out the conduct of classes amidst pandemic. It is a commitment of the government in protecting the health and safety of learners, teachers, and school personnel under the health protocol of the Department of Health (DOH) and the World Health Organization (DepEd Order Nos. 12 and 13, 2020). Apart from the LCP, all private basic education institutions are required to come up with the school plan for compliance with the minimum health standards as per $\mathrm{DOH}$ guidelines on the risk-based public health standards for COVID-19 mitigation (DOH AO No.0015, 2020). All these requirements need to be submitted to DepEd office before the opening of the school year 2020 - 2021 (DepEd Order No. 14, 2020).

\subsection{The Learning Continuity Plan}

Per DepEd Order Nos. 12 and 13 s. 2020, the LCP contains two major parts: the rationale and the operationalization home-based learning through modular, online or a 
INTERNATIONAL JOURNAL OF EDUCATIONAL MANAGEMENT AND

DEVELOPMENT STUDIES

Volume 1, Issue 1 • September 2020 • ISSN 2719-0633 (PRINT) 2719-0641 (ONLINE)

combination of modular and online (blended approach). The rationale is an easy part of the LCP as it only indicates the nature of the school which include government recognition or permit number, accreditation, and its classification whether small, medium or big school. It also includes the location of the school, summary of the number of students for the past two school years, number of administrators, teaching and non-teaching staff, and number of classrooms and other facilities. The number of currently enrolled students are included in the rationale. In reality, this part shows a drastic decrease on the number of current enrolment in most of the private basic education institutions as compared to the past two years data. This is because most of the students transferred to the public school. It was clearly stated by DepEd Secretary in the interview conducted by Rappler on 08 July 2020 that the transfer of students to public schools is due to the economic downturn. Parents who used to send their child in the private schools have lost their jobs during the pandemic. She also said that almost 200,000 students from private schools had transferred to public schools.

The operationalization part of the LCP is a very comprehensive plan in response to the new normal in education. This part needs strategic planning and coordination with the stakeholders in order to come up with a comprehensive contents as per DepEd guidelines. The operationalization part include 10 major contents which are school readiness, platform and support, content, assessments, teachers preparation, learners capability, parents role, communication plan, continuance, and monitoring and evaluation. All these require proper preparation, brainstorming, meeting, survey and coordination.

Briones (2020), DepEd Secretary, emphasized that the basic education learning continuity plan in the time of Covid-19 is the response of the department to the challenges posed by Covid-19 in the field of education. She pointed out that education must continue whatever the challenges and difficulties faced now and in the future. Thus, the LCP is an integrated output of the Department in consultations with advisers, legislators, executive directors, teachers, parents, learners and the general public.

\subsubsection{School Readiness}

All private basic education institutions must have a clear statement of its readiness in the new normal. This readiness include consultation with stakeholders as to how the new normal would take place such as online enrollment, the date of school opening, teaching and 
INTERNATIONAL JOURNAL OF EDUCATIONAL MANAGEMENT AND

DEVELOPMENT STUDIES

Volume 1, Issue 1 • September 2020 • ISSN 2719-0633 (PRINT) 2719-0641 (ONLINE)

learning modality, and the availability of the learning resources. A sample class program needs to be presented on this content. In this item, the DepEd wants to find out if the private basic education institutions are ready to continue their services to their stakeholders during the pandemic. Hernando-Malipot (2020) cites the DepEd directive that as long as no face-toface classes, basic private education institutions and other non-DepEd schools are allowed to continue their respective school openings. The non-DepEd schools which started or scheduled to start their classes are allowed to proceed with the provision of using distance learning (DLE). However, parents assert that this 'home schooling' scenario is unfavorable to the students. Burges et al. (2020) agree that home schooling is not only a massive shock to parents but also to the social life and learning of the students.

\subsubsection{Teaching and Learning Modality (Platform)}

This is a clear statement on the flow of the learning delivery mode in the new normal. Private basic education institutions have an option on the teaching and learning modality. Since DLE is encouraged, the online teaching is the most feasible option. However, not all academic institutions are prepared and have the resources to adopt the online teaching. Thus, the blended approach, a combination of synchronous and asynchronous teaching and learning modality, is the option of most of the private basic education institutions. Lawless (2019) describes blended approach as a learning modality that combines online learning where there is an interaction between teachers and students using specific platform and offline learning wherein students are given time to work on various performance tasks at their own pace.

\section{A. Asynchronous Learning}

This type of learning is known as an independent learning where students learn at their own pace. Its premise is learning in different times and spaces (Finol, 2020). The students are provided with learning materials like modules, workbook, worksheet and textbook that aid in their independent learning process. Students in this learning modality have one common communication channel either email, learning management system (LMS), Moodle or any other social media platforms that give students access to the learning materials. This modality is based on constructivism theory where students are actively constructing their own knowledge through their own experiences (Elliott, 2000, p. 256). 
INTERNATIONAL JOURNAL OF EDUCATIONAL MANAGEMENT AND

DEVELOPMENT STUDIES

Volume 1, Issue 1 • September 2020 • ISSN 2719-0633 (PRINT) 2719-0641 (ONLINE)

According to Gardiner (2020), this mode is specifically helpful for students with difficulty attending specific time schedules. It also allows peer collaboration through group assignments where students can work and review tasks together. Ultimately, this aids to those with no full access to the internet.

For academic institutions with their own LMS, management of the learning materials is easy for both the teachers and the students. All quizzes, class works and other performance tasks including quarterly assessments can be made readily available. The user administrators can also create email accounts for students using Microsoft Office 365 for easy communication. However, schools with insufficient funds and resources make full use of the modular approach. If no available platform for the upload of the learning materials, parents can claim materials from the school observing proper protocols. In reality, this allows teachers to work at home while students learn at home at their own pace. However, a serious issue is on the online assessments. Online examinations through a 'trial and error' approach lead to uncertainty. Interruptions and internet glitches affect students' performance that might lead to increased failures. Results might not be favorable for both the teachers and the students. Gardiner (2020) shares best practices for asynchronous learning. One powerful way is through a record of any components of the syllabus. It is mandatory also to communicate with the students and provide specific instructions either through email or a discussion thread in a portal.

\section{B. Synchronous Learning}

This is a real time online learning with live interaction between teacher and students using specific online platforms. The learners and teachers are in the same place online at the same time for learning to take place (Finol, 202). It includes video conferencing, livestreaming lectures and chatting using Google classroom, Google meet, Zoom, MS Teams, and other platforms (The Best School, 2018). This allows similar face to face classes through a virtual room. For most of the learners, it gives opportunity for online interactions (Simonson, Smaldino, Albright, \& Zvacek, 2012), allows immediate question and answer session (Hrastinski, 2008) and offers personalized learning opportunities (Lorenzo \& Ittelson, 2005). For example, in a study conducted by Park \& Bonk (2007) in a synchronous graduate class found that there was no difference between the online and in-class students in terms of 
INTERNATIONAL JOURNAL OF EDUCATIONAL MANAGEMENT AND

DEVELOPMENT STUDIES

Volume 1, Issue 1 • September 2020 • ISSN 2719-0633 (PRINT) 2719-0641 (ONLINE)

learning strategies for synchronous discussions. However, the case is very much different for the school children.

Hrastinski (2008) provided a clear view as to when, why and how to use asynchronous and synchronous e-learning as provided in table 1.

\section{Table 1}

When, Why, and How to Use Asynchronous vs. Synchronous E-Learning

\begin{tabular}{|c|c|c|}
\hline & Asynchronous E-Learning & Synchronous E-Learning \\
\hline When? & $\begin{array}{l}\text { Reflecting on complex issues } \\
\text { When synchronous meetings } \\
\text { cannot be scheduled because } \\
\text { of work, family, and other } \\
\text { commitments }\end{array}$ & $\begin{array}{l}\text { Discussing less complex } \\
\text { issues } \\
\text { Getting acquainted } \\
\text { Planning tasks }\end{array}$ \\
\hline Why? & $\begin{array}{l}\text { Students have more time to } \\
\text { reflect because the sender } \\
\text { does not expect an immediate } \\
\text { answer. }\end{array}$ & $\begin{array}{l}\text { Students become more } \\
\text { committed and motivated } \\
\text { because a quick response is } \\
\text { expected. }\end{array}$ \\
\hline How? & $\begin{array}{l}\text { Use asynchronous means } \\
\text { such as e-mail, discussion } \\
\text { boards, and blogs. }\end{array}$ & $\begin{array}{l}\text { Use synchronous means such } \\
\text { as videoconferencing, instant } \\
\text { messaging and chat, and } \\
\text { complement with face-to- } \\
\text { face meetings. }\end{array}$ \\
\hline Examples & $\begin{array}{l}\text { Students expected to reflect } \\
\text { individually on course topics } \\
\text { may be asked to maintain a } \\
\text { blog. } \\
\text { Students expected to share } \\
\text { reflections regarding course } \\
\text { topics and critically assess } \\
\text { their peers' ideas may be } \\
\text { asked to participate in online } \\
\text { discussions on a discussion } \\
\text { board. }\end{array}$ & $\begin{array}{l}\text { Students expected to work in } \\
\text { groups may be advised to use } \\
\text { instant messaging as support } \\
\text { for getting to know each } \\
\text { other, exchanging ideas, and } \\
\text { planning tasks. } \\
\text { A teacher who wants to } \\
\text { present concepts from the } \\
\text { literature in a simplified way } \\
\text { might give an online lecture } \\
\text { by videoconferencing. }\end{array}$ \\
\hline
\end{tabular}

Source: Stefan Hrastinski (2008) 
INTERNATIONAL JOURNAL OF EDUCATIONAL MANAGEMENT AND

DEVELOPMENT STUDIES

Volume 1, Issue 1 • September 2020 • ISSN 2719-0633 (PRINT) 2719-0641 (ONLINE)

\section{Blended Learning}

A survey has to be carried out prior to the selection of learning modality to be used. Taking the current situation in the country as rank 104 among 160 countries in internet connectivity, Salac \& Kim (2020) admit that the internet infrastructures are behind the developing countries in Asia. It is also a fact that not all students have access to internet and technology. Since the learning modality entails the use of internet connection, situation presses for a blended approach, a combination of asynchronous (offline) and synchronous (online).

For Shank (2020), the use of synchronous sessions can be recorded as part of the asynchronous model. This allows students to access the recordings at any time during their independent learning hours. In a study conducted by Perveen (2016) in Pakistan among 1025 undergraduate students, it was found that the asynchronous learning was quite beneficial for second language learners with scaffolding by synchronous sessions. The author suggests for a blended approach as an ideal model for e-learning.

\subsubsection{Curriculum Contents}

The curriculum contents in the distance learning is based on the revised Most Essential Learning Competencies (MELCs) set by DepEd. A clear statement of the quarter calendar showing the learning areas to be covered each quarter is required to be stated in the LCP. All private basic education institutions need to clearly present a statement indicating the learning areas students need to undertake for the whole year. Course requirements are indicated to ensure that the intended learning outcomes are met after every quarter. In the case of blended approach, a sample copy of prepared workbook and/or worksheet are presented or attached as part of the annexes.

To address the impact of Covid-19 in the Philippines, DepEd affirms its commitment on the delivery of quality education relevant to the basic education services anchored on its slogan "Sulong Edukalidad" framework (Pascua, 2020). It was also pointed out that the revised MELCs are part of the DepEd's response to develop resilient education system especially during emergencies to be rolled out for SY 2020 - 2021. Thus, the private basic education institutions are required to follow the MELCs to continuously produce holistic 
INTERNATIONAL JOURNAL OF EDUCATIONAL MANAGEMENT AND

DEVELOPMENT STUDIES

Volume 1, Issue 1 • September 2020 • ISSN 2719-0633 (PRINT) 2719-0641 (ONLINE)

Filipino learners acquiring the $21^{\text {st }}$ century skills despite the use of blended or distance learning.

\subsubsection{Assessments}

Learning outcomes in the form of knowledge, skills, attitudes, and values are the major measures of the teaching and learning in the basic education. This part needs a clear statement that the assessments are still in compliance with the DepEd's standard indicating the required percentage in each of the components including written work, performance task, and quarterly assessments. According to the DepEd Order No. 8, (2015), classroom assessment is an integral part on the implementation of the curriculum. It becomes the bases for measuring the performance and progression of the students. This also acts as parameter for the necessary adjustments on the teaching strategies as set in the policy guidelines.

According to Russell (2001), there is no difference in the achievement of learning outcomes as measure in grades or exams between the face to face and e-learning modality. The same was the results of the study conducted by Francescucci \& Rohani (2018) on the 698 undergraduate students in North America. The specific statistical comparison between the face to face and the virtual, interactive, real-time, instructor-led (VIRI) showed same level of students performance in both methods. Given the results of the previous studies, the adaption of the e-learning at the current state may not be similar in the outcomes. There are various considerations such as the attention span of the children, the assessment mode, monitoring and supervision during assessment and other social and environmental factors.

\subsubsection{Teacher's Role}

The role of the teacher in the new normal plays a big part on the teaching and learning process using the chosen modality. The role is expanded as compared to the normal classroom setup. In the new normal, the teachers must be available at all times even though they are working at home. Although a bit burden for the teachers, they need to be available online at all times in case of queries from the students and parents. As Tarek (2016) emphasized that since distance learning entails high level of interaction between the teacher

and students, the teacher must treat learning problems that students might encounter taking into account the individual needs of the students in terms of their learning styles. Teachers 


\section{INTERNATIONAL JOURNAL OF EDUCATIONAL MANAGEMENT AND \\ DEVELOPMENT STUDIES \\ Volume 1, Issue 1 • September 2020 • ISSN 2719-0633 (PRINT) 2719-0641 (ONLINE)}

must initiate virtual learning activities such as collaborative work to motivate students to learn. They should be more creative, motivate their students to actively participate in the virtual learning and engage the students to a deeper learning so that the desired learning outcomes are met (Tuscano, 2020).

Saxena \& Saxena (2020) developed a framework as to the role of teachers during the pandemic as shown in Figure 1. It highlights the teaching levels for effective learning which enable to unfold the fears and mysteries of immature learners.

\section{Figure 1}

\section{Teaching levels for effective learning}

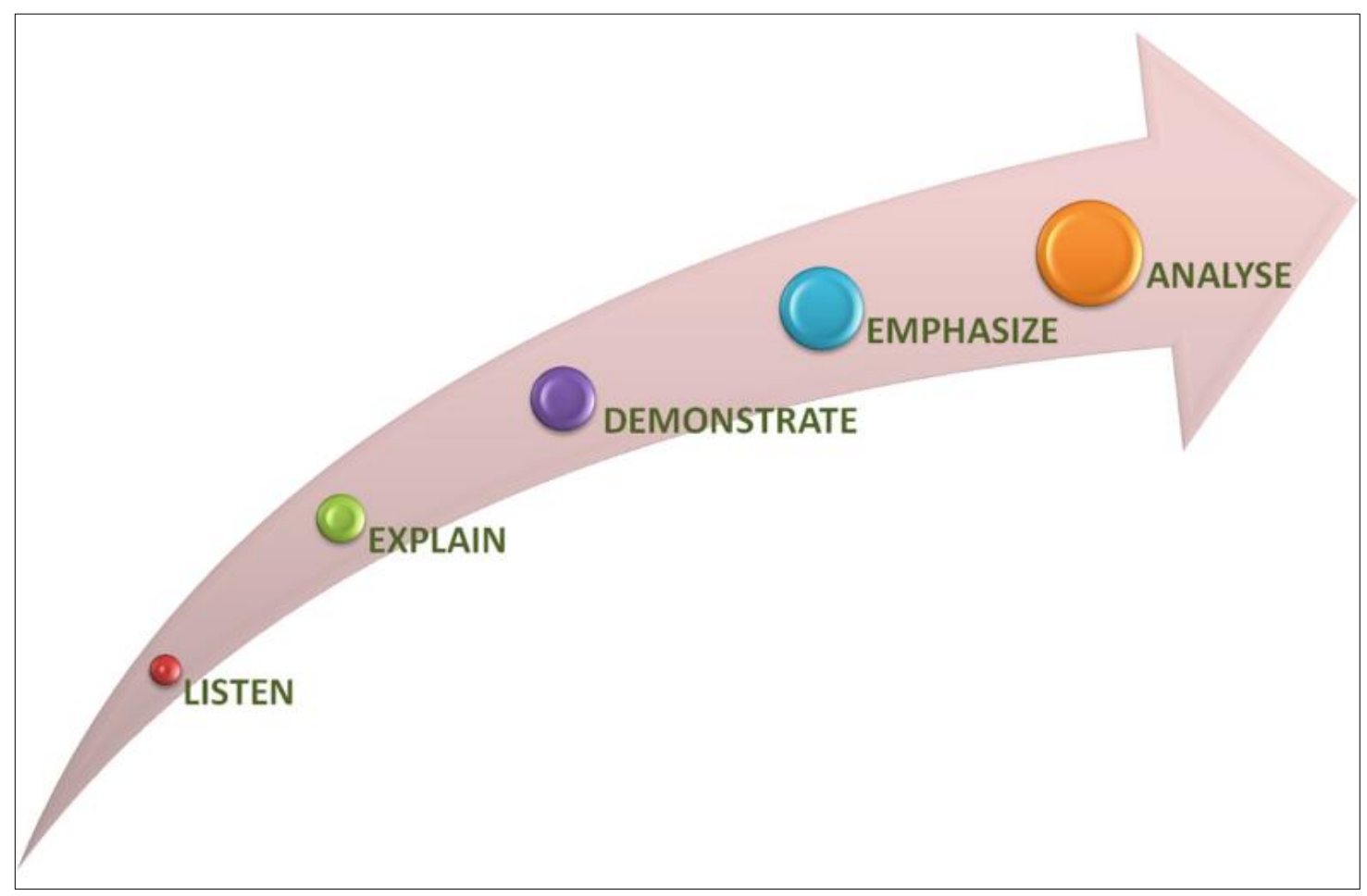

Source: Saxena \& Saxena (2020). Available at https://media.springernature.com/original/springerstatic/image/chp\%3A10.1007\%2F978-981-15-4814-7_15/MediaObjects/498571_1_En_15_Fig4_HTML.png

As the children have different nature and learning styles, teachers need to develop different teaching levels suitable to the students. Aside from the different teaching strategies, Warden, Stanworth, Ren \& Warden (2013) disclosed the result of the nine-year action research on 3630 students that the main source of problem in the synchronous learning is behavior. Thus, the virtual classroom management is a measure of success in the new normal 
INTERNATIONAL JOURNAL OF EDUCATIONAL MANAGEMENT AND

DEVELOPMENT STUDIES

Volume 1, Issue 1 · September 2020 • ISSN 2719-0633 (PRINT) 2719-0641 (ONLINE)

of teaching. On the other hand, Bower, Dalgarno \& Kennedy (2013) found that the main challenge in blended learning were communication and split attention. Given the current situation worldwide, it is the prime responsibility of the teacher to ease the fears and anxieties of the children. In reality, it will not be easy to educate the children something beyond their grasps such as the pandemic. For this, training of teachers on the facilitation of the new normal teaching and learning is indeed necessary requirement. Certification and training programs on the use of various platforms is required as well us preparation of modules and workbooks.

\subsubsection{Learner's Role}

In the new normal, learning on the part of the students is a drastic change be it online class using a platform or offline classes through independent learning. Since students are used to face to face interaction with the teacher, it will be quite difficult for them to suddenly adjust to the new system. It requires proper orientation and familiarization of the new normal. The learners need to be encouraged to adapt the new learning modality and understand the lessons at their own pace with the assistance of their parents and or guardian.

\subsubsection{Parents' Role}

The parents play a big role in the academic performance of their child in the new normal of teaching and learning. Their critical role is addressed at the beginning through a consultative session in the adaption of the learning modality. According to Kuruvilla (2020), the role of parents in the virtual learning is important. Since students are home-schooled, they have to monitor the development and performance of their child on their day-to-day activities during the independent learning hours. Without the help of the parents, teachers will not be able to meet the desired learning outcomes at the end of the day.

According to Rich (2020) parents should cast their children's fears of the situation. The stress and anxiety level of the children increase due to the challenging times. Their role intensifies as their children are home-schooled. They should be keen on the problematic reactions of their children as it increases their stress level. It is advisable to have reasonable distractions while doing independent learning. Saxena \& Saxena (2020) suggest that parents control their anxiety first and be in stable mental health condition before facing their 
INTERNATIONAL JOURNAL OF EDUCATIONAL MANAGEMENT AND

DEVELOPMENT STUDIES

Volume 1, Issue 1 • September 2020 • ISSN 2719-0633 (PRINT) 2719-0641 (ONLINE)

children. The support of the parents is critical to the learning development of the children in the absence of the teachers.

\subsubsection{Communication Plan}

Communication plays an important role in the implementation of the new teaching and learning modality. Haythornthwaite (2002) suggests the three types of communication in sustaining e-learning communities: content-related communication, planning of tasks and social support. It serves as a road map on how teachers, learners and parents connect with each other. To be transparent with the stakeholders, a statement on the medium to be used need to be stated clearly. There is a clear process on how important information, announcements and other updates reach the stakeholders. Everitt (2020) emphasizes that transparency to stakeholders is very important to maintain the two-way communication about the status of the newly implemented program.

\subsubsection{Continuance}

The school pledges that teachers have continuous learning and enhancement program on the use of technology and other platforms. For this, an explicit statement is needed in the LCP to ensure quality in the teaching and learning process. In addition, the school certifies the statement through a plan of continuous improvement of its quality services in terms of training and seminars before, during and after the delivery of the new modality. According to teacher.org (2020), professional development for teachers is very important as education is an ever growing and changing field. This means that teachers must be updated of the current trends in educational practice. However, teachers in the private schools cannot afford professional development due to high cost of the training programs. Much more depressing is that schools cannot finance their own teachers' professional development. As a solution, schools only give free in-house training for their teachers sponsored by some publishing book companies.

\subsubsection{Monitoring and Evaluation}

Under the new normal, efficacy of the monitoring and evaluation process is necessary. For example, learners who were given the learning resources need to be evaluated 
INTERNATIONAL JOURNAL OF EDUCATIONAL MANAGEMENT AND

DEVELOPMENT STUDIES

Volume 1, Issue 1 • September 2020 • ISSN 2719-0633 (PRINT) 2719-0641 (ONLINE)

and monitored both for the learning process and the applicability of the learning modality. Support system is established for monitoring. In this case, feedbacks from students and parents are necessary to identify major gaps in the implementation and provide inputs for the improvement of the chosen platform. According to Kamalludeen (2020), alternative means of evaluation have to be used to monitor the students' progress and achievement. The evaluation must focus on the results of students' performance to measure the achievement of the learning outcomes.

\subsection{School's Plan for Compliance with Minimum Health Standards}

\subsubsection{Protocols for Health and Safety}

DepEd Order No. 14, s. 2020 instructs all private basic education institutions to come up with health and safety protocols in compliance with the guidelines on the risk-based public health standards for COVID-19 mitigation. This Covid-19 mitigation aims to increase mental and physical resilience, reduce transmission and contact, and reduce duration of infection (DOH AO No. 0015, 2020). For this, the UNICEF (2020) emphasizes on the water and hygiene facilities.

\section{A. General Health and Safety Protocols}

In compliance with the DOH guidelines on the risk-based public health standards for covid-19 mitigation, the general health and safety protocols advocate the use and practice of respiratory etiquette and other protective measures. All learners, teachers, and non-teaching personnel are required to observe this general health safety protocols through the use of protective measures. Additionally, the school needs to ensure the availability of disinfecting paraphernalia at all times. Singh-Vergeire (2020) explains that the public must be vigilant and observe the infection prevention such as the use of PPEs, proper hygiene and social distancing to avoid the spread of the virus.

\section{B. Detection and Referral}

Early detection through temperature check of all who enters the school premise is a primary step in times of pandemic. In case someone is detected to have high temperature, 
INTERNATIONAL JOURNAL OF EDUCATIONAL MANAGEMENT AND

DEVELOPMENT STUDIES

Volume 1, Issue 1 • September 2020 • ISSN 2719-0633 (PRINT) 2719-0641 (ONLINE)

referral to the nearby local health unit is a must. This is an additional challenge to the school as they are responsible for the monitoring of students and teachers with or without disease symptoms. The responsibilities of the school administration extends to the implement of this policy to maintain safety within the school community. Bender (2020) emphasizes that the school community must promote information sharing including prevention and control measures and follow the guidelines set by the health authorities.

\section{School Activities and Events}

Curricular and co-curricular activities are part of the teaching and learning process. These help learners develop their skills and talents. Naii (2018) points out that extracurricular activities provide students with self-confidence to become a well-rounded individual. However, for the current school year, all school activities are postponed except those that can be done through online. DepEd Order No. 13, s. 2020 reiterates that all activities of the private basic education institutions are postponed for the entire school year 2020-2021. Postponement of the school's extracurricular and co-curricular activities like field trips, school retreat, foundation day and other activities will surely be missed by the students this school year.

\section{School Clinic and Health Services}

The school clinic plays a big role on the students' health and safety. The school has to ensure that teachers and other school personnel who manifest symptoms shall not be allowed to report to school. The school clinic also needs to coordinate with the local health authorities in tracing and quarantine of confirmed positive cases. The school clinic ensures the availability of emergency health kits that include PPEs and other needed supplies and materials. The role of the school management in the protection, detection, prevention, and monitoring of the school community plays a big role in times of pandemic (Vergeire, 2020).

\subsubsection{Physical Arrangement in School}

In times of pandemic, physical arrangement of the school complies with the DOH guidelines. All classrooms must meet the standards prescribed by the DOH to avoid the spread of the virus. This includes proper ventilation, proper sanitation and hygiene facilities. 
INTERNATIONAL JOURNAL OF EDUCATIONAL MANAGEMENT AND

DEVELOPMENT STUDIES

Volume 1, Issue 1 • September 2020 • ISSN 2719-0633 (PRINT) 2719-0641 (ONLINE)

Even though students are not coming to school, the physical arrangement of the school has to follow the standards set by the government (DepEd Order No. 13, 2020).

\subsubsection{Support Mechanisms}

This includes physical and mental resilience and administrative support of the school. The first step to achieve resilience is through proper orientation to its teachers and learners. Furthermore, the school guidance office must be functioning effectively in monitoring students' mental health. The school also makes sure that teachers working at home are provided with necessary logistics.

\section{Conclusion}

It is obvious that almost all private basic education institutions are facing lot of challenges brought by the effect of covid-19 pandemic. The government order on the stoppage of face-to-face classes until vaccine is available has impacted on the enrollment data of the basic private education institutions. The decrease on the number of enrolment is due to economic downturn as parents who can afford high fees in the private schools lost their jobs during the pandemic. In addition, the sudden shift on the teaching and learning modality added burden and pressures to the school owners.

The DepEd requires all private basic education institutions have to comply with all the government requirements if teaching and learning are pursued for the current school year. Of these requirements, the LCP and health and safety protocols add additional burden as these are for strict compliance and immediate implementation. Though DepEd gave guidelines on how to prepare all the requirements for the opening of classes, the documentation process is a tedious process completed in no time. The bigger challenge is now passed on to the private schools.

Literature cited herein develop a framework as to the necessary measures every private basic education institutions must do in the re-opening of the schools. As there are limited studies written on the same nature, the current situation serves as a jumpstart in the conduct of the same. Children by nature are more exposed to face-to-face learning but, as the situation dictates, have to transition to e-learning with no bridging programs. As the old 
INTERNATIONAL JOURNAL OF EDUCATIONAL MANAGEMENT AND

DEVELOPMENT STUDIES

Volume 1, Issue 1 • September 2020 • ISSN 2719-0633 (PRINT) 2719-0641 (ONLINE)

adage says 'experience is the best teacher', the author suggests a thorough study on the various facets of the online learning involving the children of the private basic education institutions.

\section{References}

Acidre, J. (2019). Private Education, Available online at www.manilastandard.net, Date Accessed, 14 August 2020.

Bender, L. (2020). Key Messages and Actions for Covid-19 Prevention and Control in School, Unicef and World Health Organization, March 2020.

Bower, M., Dalgarno, M.J. \& Kennedy, G.E. (2013). Blended Synchronous Learning: Patterns And Principles For Simultaneously Engaging Co-Located And Distributed Learners. 30th ascilite Conference 2013 Proceedings, pp $92-102$

Briones, L. (2020). Education in the Philippines, Available online at www.rappler.com, Date Accessed 18 August 2020.

Carcamo, D. (2014). Creation of Bureau of Private Schools. Available online at www.philstar.com, Date Accessed, 14 August 2020.

DepEd Order No. 007 s. 2020. Private School Requirements for the Opening of Classes for SY 2020- 2021, Available online at www.deped.gov.ph, Date Accessed 8 August 2020.

DepeD Order No. 012 and 013 (2020). Basic Education Learning Continuity Plan for Private Schools, Available online at www.deped.gov.ph, Date Accessed, 27 July 2020.

DepEd Order No. 14 (2020). School Plans for Compliance with Minimum Health Standards, Available online at www.deped.gov.ph, Date Accessed 8 August 2020.

DepEd Order No. 8 (2015). Classroom Assessment guidelines. Available online at www.deped.gov.ph, Date Accessed, 15 August 2020.

DOH AO No. 0015 (2020). DOH Guidelines on the Risk-Based Public Health Standards for COVID-19 Mitigation, Available online at www.doh.gov.ph, Date Accessed, 10 August 2020.

Elliott, S.N. et. al., (2000) Educational Psychology: Effective teaching and learning, $3^{\text {rd }}$ edition, Boston, MA: Mc-Graw-Hill College .

Everitt, J (2020). How to Get Stakeholders on Your Side With Campaign Transparency, Available online at www.wrike.com, Date Access, 16 August 2020.

Felter, C. \& Maizland, L. (2020). How Countries Are Reopening Schools During the Pandemic. Council of Foreign Relations. Available online at: https://www.cfr.org/backgrounder/how-countries-are-reopening-schools-duringpandemic. Date Accessed, 28 July 2020.

Finol, M.O. (2020). Asynchronous vs. Synchronous Learning: A Quick Overview. Available online at: https://www.brynmawr.edu/blendedlearning/asynchronous-vs-synchronouslearning-quick-overview. Date Accessed, 28 July 2020.

Francescucci, A. \& Rohani, L. (2018). Exclusively Synchronous Online (VIRI) Learning: The Impact on Student Performance and Engagement Outcomes. Journal of Marketing Education. Volume: 41 issue: 1, page(s): 60-69. DOI: https://doi.org/10.1177/0273475318818864 


\section{INTERNATIONAL JOURNAL OF EDUCATIONAL MANAGEMENT AND \\ DEVELOPMENT STUDIES \\ Volume 1, Issue 1 • September 2020 • ISSN 2719-0633 (PRINT) 2719-0641 (ONLINE)}

Gardiner, E. (2020). Remote Teaching: When and How to Use Synchronous vs. Asynchronous Methods. Available online at: https://tophat.com/blog/remote-teachingwhen-and-how-to-use-synchronous-vs-asynchronous-methods/. Date Accessed, 28 July 2020.

Haythornthwaite, C. (2002). Building Social Networks via Computer Networks: Creating and Sustaining Distributed Learning Communities, in Building Virtual Communities: Learning and Change in Cyberspace, K. Ann Renninger and Wesley Schumar, eds. Cambridge: Cambridge University Press, pp. 159-190.

Hernando-Malipot M. (2020). DepEd Private Schools allowed to open classes ahead of October 5, Published in the Manila Bulletin, 15 August, 2020.

Hrastinski, S. (2008). Asynchronous \& Synchronous e-learning. Educause Quarterly. Number 4 2008, pp $51-55$

Kamalludeen, R. (2020). Transitioning to the new normal in education, Available online at www.thestar.com.my, Date Accessed, 16 August 2020.

Kuruvilla, A (2020). Virtual Learning: The 'New Normal' in Imparting Lessons to the Students, Available online at www.indianexpress.com, Date Accessed, 16 August 2020.

Lawles, C. (2019). What is Blended Learning? Available online at www.learnupon.com, Date Accessed, 15 August 2020.

Magsambol, B. (2020). No student left behind? During pandemic, education 'only for those who can afford'. Rappler. Available online at https://rappler.com/newsbreak/indepth/education-only-for-people-who-can-afford-coronavirus-pandemic. Date Accessed, 24 June 2020.

Magsambol, B. (2020). Over 200,000 students transfer from private to public schools amid pandemic. Rappler. Available online at https://rappler.com/nation/students-privateschools-transfer-to-public-coronavirus-pandemic. Date Accessed, 18 July 2020.

Naik, N. (2018). Importance of Extracurricular Activities in School Life, Available online at www.yourstory.com, Date Accessed, 17 August 2020.

Park, Y.J. \& Bonk, C.J. (2007). Synchronous Learning Experiences: Distance and Residential Learners' Perspectives in a Blended Graduate Course. Journal of Interactive Online Learning. Volume 6, Number 3, pp 245 - 264

Pascua, A. (2020). K to 12 Most Essential Learning Competencies. Available online at www.deped.gov.ph, Date Accessed, 15 August 2020.

Perveen, A. (2016). Synchronous and Asynchronous E-Language Learning: A Case Study of Virtual University of Pakistan. Open Praxis, Vol. 8 issue 1, January-March 2016, pp. 21-39

Rich, M. (2020). 6 ways parents can support their kids through the coronavirus disease (COVID-19) outbreak. Available online at: https://www.unicef.org/coronavirus. Date Accessed, 28 July 2020.

Russell, T.L. (2001). The No Significant Difference Phenomenon, $5^{\text {th }}$ ed. Montgomery, AL: International Distance Education Certification Center

Salac, R.A. \& Kim, Y.S. (2016). A Study on The Internet Connectivity in The Philippines. Asia Pacific Journal of Business Review 1(1):67-88. DOI: 10.20522/APJBR.2016.1.1.67

Saxena R., Saxena S.K. (2020). Preparing Children for Pandemics. In: Saxena S. (eds) Coronavirus Disease 2019 (COVID-19). Medical Virology: From Pathogenesis to 
INTERNATIONAL JOURNAL OF EDUCATIONAL MANAGEMENT AND

DEVELOPMENT STUDIES

Volume 1, Issue 1 • September 2020 • ISSN 2719-0633 (PRINT) 2719-0641 (ONLINE)

Disease Control. Springer, Singapore. https://doi.org/10.1007/978-981-15-48147 . 15

Shank, P. (2020). (The Right) Learning Modalities to Deliver Digital Learning: Part 4. Available online at: https://elearningindustry.com/create-synchronous-learningdigital-modalities-part-4. Date Accessed, 28 July 2020.

Simon Burgess, Hans Henrick Sieversten (2020). Schools, skills, and learning: The impact of COVID-19 on education, Available online at www.voxeu.org, Date Accessed 24 June 2020.

Singh-Vergiere (2020). Safety Prevention Protocols Against Covid-19, Press Release, Department of Health, July 10, 2020.

Snyder, H. (2019). Literature Review as Research Methodology: An Overview and Guidelines, Journal of Business Research, Vol. 104, p 1.

Tanhueco-Tumapon (2020). Education and the New Normal. Available online at www.manilatimes.net, Date Accessed, 26 July 2020.

Tarek, S. (2016). Distance Learning: The Role of the Teacher, Available online at www.docuri.com, Date Accessed, 15 August 2015.

The Best School (2018). Synchronous Learning Vs. Asynchronous Learning in Online Education, Available online at www.thebestschools.org, Date Accessed, 26 July 2020.

Tuscano, F. (2020). It's not about Online Learning: A Reflection on the "New Normal" in Education, Available online at www.francisjimtuscano.com, Date Accessed 16 August 2020.

UNESCO (2020). Education: From disruption to recovery, Available online at www.en.unesco.org, Date Accessed, 24 June 2020.

Warden, C.A., Stanworth, J.O., Ren, J.B. \& Warden, A.R. (2013). Synchronous learning best practices: An action research study. Computers \& Education, Volume 63, April 2013, Pages 197-207. DOI: https://doi.org/10.1016/j.compedu.2012.11.010 